YEARBOOK

of ANTITRUST

and REGULATORY

STUDIES

www.yars.wz.uw.edu.pl
Peer-reviewed scientific periodical, focusing on legal and economic issues of antitrust and regulation.

Creative Commons Attribution-No Derivative Works 3.0 Poland License.

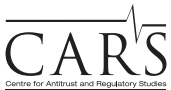

Centre for Antitrust and Regulatory Studies, University of Warsaw, Faculty of Management www.cars.wZ.uw.edu.pl

\title{
Guidance on the Limits for the Use of Restrictive Clauses in Commercial Lease Agreements - Once Again on Restrictions "by Object". \\ Case Comment to the Preliminary Ruling of the Court of Justice of 26 November 2015 SIA 'Maxima Latvija' v Konkurences padome (Case C-345/14)
}

by

\section{Olga Stefanowicz ${ }^{*}$}

\section{CONTENTS}

I. Preliminary summary

II. Legal context

III. Key findings of the CJ

IV. Analysis

1. Vertical character of the right to veto

2. Current state of "by object" matters

3. Recent examples of the application of "by object"

4. Logic and features of the "object box"

V. Three-tier analysis

VI. Decisive impact of market foreclosure

VII. Code of conduct

VIII. Conclusion

* LL.M. (FU), PhD candidate at University of Wrocław (EMS), Poland; olgastefanowicz@ yahoo.pl. Article received: 11 July 2016; accepted: 18 October 2016.

Ministry of Science and Higher Education

Republic of Poland
The creation of the English-language version of these publications is financed in the framework of contract No. 768/P-DUN/2016 by the Ministry of Science and Higher Education committed to activities aimed at the promotion of education. 
Key words: anti-competitive agreement; non-compete clause; vertical restriction; Article 101 TFEU; by object; by effect; market foreclosure; commercial lease agreement; shopping centres; analogous national legislation; Latvia.

JEL: K21; K42

\section{Preliminary summary}

The Court of Justice (hereinafter, CJ or Court) held in case C-345/14 SIA 'Maxima Latvija' $v$ Konkurences padome that the inclusion of a clause that allows a tenant to indirectly select a neighbour of adjoining shopping centre spaces is not a restriction "by object". On the example of Maxima Latvija (a supermarket chain active predominantly in the food sector), the CJ outlined under which conditions can competition law concerns arise from non-compete clauses in lease agreements concerning shop premises. The existence of a right to veto over potential tenants of adjourning shop premises may have the effect of restricting competition within the meaning of Article 101(1) TFEU, and should thus be assessed according to its market impact. Although the Court recognised that a unilateral decision on the lease of other commercial spaces is not by its nature anti-competitive, an effect-based assessment would require a multi-faceted analysis, which might still find a competition law infringement. Although the multi-criteria analysis proposed by the CJ is somewhat blurry, the judgment is a valuable contribution to the debate on the restrictive interpretation of "by object" restrictions.

What certainly emerged from the CJ's standpoint in Maxima Latvija is a clarification of the "object" criterion, which has for some time now been in a state of flux. On the one hand, Maxima Latvija acts as a reminder to be well aware of contractual non-compete arrangements. On the other, the judgment provides comments on legal framework of vital character. However, while the remarks of the Court are meaningful, they remain vague. Nevertheless, as things stand, the $\mathrm{CJ}$ emphasised that the approach towards object restrictions cannot be too simplistic. The Maxima Latvija judgment offers a reliable approach whereby the judiciary should examine the context of each case before them, identify the type of arrangements in place, and check whether the behaviour is really "bad". Although the content of the judgment does not provide much detail on why the potential harm contained in the scrutinised lease agreements (or more precisely, in the contested clause introduced into them) was ruled as not harmful enough, the fact has to be welcomed that the Court then looked at the clause's effects. This is obviously also good news for undertakings active in shopping malls. However, the approach taken in the 
Maxima Latvija case, apart from accurate practical and doctrinal remarks, simply does not provide them with sufficient indications how to avoid similar competition concerns in the future. There are therefore two ways out: if not to use an extended economic market analysis than to use the trial and error method, albeit the application of the latter could be costly in practice.

The article discusses the state of the law in the Maxima Latvija judgment, regulatory interest in the maintenance of a division into two types of competition restrictions, and some nuances noted by the Court in its judgment that are nevertheless of major significance, likely to influence future cases on contractual exclusivity in vertical relations.

\section{Legal context}

The retail food trade market is often recognised as problematic when it comes to the application of competition law provisions. Problems appear most frequently in the horizontal context, when competition authorities face complaints from small retailers and regarding practices conducted by largeformat stores. Vertical restrictions are observed less often but they tend to cause more (or more complex) anti-competitive problems, a fact that was part of the reasoning in the Maxima Latvija case.

The request for a primary ruling from the Augstākā Tiesa (Supreme Court) concerned the interpretation of Article 101(1) TFEU as regards a fine imposed on Maxima Latvija (hereinafter, Company) for having concluded a series of commercial lease agreements with shopping centres. The investigated agreements contained a clause granting the Company (strategic tenant), the right to agree to the shopping centre (lessor) renting to third parties commercial premises not rented to the Company. According to the Latvian Competition Council (hereinafter, Council), the contested clause constituted a vertical restraint, the object of which was the prevention, restriction or distortion of competition. After analysing 119 of such contracts, the Council found that 12 of them contained the above anti-competitive clause. In light of this fact, the Council issued a decision imposing a fine of approximately 34,770 EUR on Maxima Latvija. The Company brought an action for annulment against that decision before the Regional Administrative Court and then appealed its judgment to the Supreme Court which referred the case to the Court of Justice. The Supreme Court saw a similarity between Latvian competition law and the wording of Article 101(1) TFEU, as well as a common public benefit of national courts applying its law in accordance with EU law. Despite the fact that the referring court found that the agreements were not of a kind that 
could affect trade between Member States, it nevertheless referred a series of questions to the $\mathrm{CJ}$ for a preliminary ruling because of their similarities in essence.

\section{Key findings of the CJ}

The Court disposed of the admissibility objection first stating that it has jurisdiction to answer the questions referred to it by the Supreme Court in the interest of certainty and uniformity of EU law even if there is no effect on EU trade of the practice at hand. The line of reasoning followed by the CJ was based on the necessity to prevent future differences in the interpretation of EU competition law, irrespective of the circumstances in which they are to apply.

The CJ began its assessment by dealing with the fundamental issue of the "object or effect" of anti-competitive conduct. As for the question whether commercial lease agreements constitute a restriction "by object", the CJ reiterated that the concept of the two types of restrictions must be interpreted restrictively ${ }^{1}$. The prohibition laid down in Article 101(1) TFEU, according to established jurisprudence starting with the L.T.M. judgment ${ }^{2}$ and a purely linguistic interpretation indicated by the conjunction "or", presumes that "an agreement must have as [its] object or effect the prevention, restriction or distortion of competition within the internal market". Such wording stresses not only a separable character of the two types of infringements, but also the need to consider the precise object of the agreement in the economic context in which it is to be applied.

Investigating the "object" should always take place by way of analysing the agreement in its context (John and Turner, 2015, p. 34). As a result, the essential criterion for ascertaining whether an agreement between undertakings restricts competition "by object" is to find that such coordination in itself "reveals sufficient degree of harm" 3 . Allocating a case to an "object box" would thus mean that a competition authority does not need to demonstrate an anticompetitive effect ${ }^{4}$. Although such approach seems to be common practice, and the CJ made it clear that this "decisional shortcut" could be taken only if

\footnotetext{
${ }^{1}$ Maxima Latvija, para. 18; see also judgment of the CJ of 11 September 2014, Case C-67/13 P CB v Commision, EU:C:2014:2204, para. 58.

2 Judgment of the ECJ of 30 June 1966, Case 56/65 Société Technique Minière (L.T.M.) v Maschinenbau Ulm GmbH (M.B.U.), EU:C:1996:38, para. 249.

${ }^{3} C B$ v Commission, para. 57.

4 See e.g. judgment of the GC of 14 March 2013, T-587/08 Fresh Del Monte Produce v Commission, EU:T:2013:129, paras 304-308.
} 
an agreement will inevitably have a harmful effect within the internal market. In practice, the Commission has several times left the question of "by object" open and still tends to provide fertile ground for further discussion as well as charges brought by the parties to the alleged anti-competitive agreements ${ }^{5}$.

According to the Court, once an "object type" restriction has been ruled out, the effect of an agreement on competition must be assessed in the economic and legal context in which it occurs, and where it might combine with others to have a cumulative effect on competition. The assessment shall take into account all of the factors which determine access to the relevant market (local retail food trade). In this sense, it would always be necessary to check whether Maxima Latvija's competitors could establish themselves in other commercial spaces and how accessible they are. Accordingly, competitive forces on the relevant market should play a major role in the assessment. Taking account of the economic context, it would be necessary to know the number and size of existing market operators as well as market concentration levels, consumer fidelity to existing brands and their habits. The position of the contracting parties and the duration of their agreements would constitute crucial factors also as only agreements that make an appreciable contribution to the closingoff of the market should be prohibited ${ }^{6}$.

\section{Analysis}

\section{Vertical character of the right to veto}

The non-compete clause in question gave the Court an opportunity to once again look closely at the subtle distinction between restrictions "by object" and "by effect". In Maxima Latvija, the CJ noted that the contested agreement, and the veto right incorporated therein, was of a vertical character. It was an agreement concluded by firms operating at different levels: a retailer and a property owner that did not compete with each other. Although vertical agreements are not normally considered as anti-competitive by their very nature, the Court looked deeper into the question how this type of agreement fits into the "by object" and "by effect" category of antitrust infringements.

5 Master Card MIF charges of 19 December 2007, COMP/34.579, paras 406-407. Charges brought in case T-111/08 MasterCard (judgment of the GC of 24 May 2012).

6 An extensive analysis of market foreclosure was conducted by the ECJ in judgment of 28 February 1991, Case C-234/89, paras 23-24. Here, beer supply agreements entered into by breweries the contribution of which to the cumulative effect was insignificant was deemed as not falling under the prohibition of Article 85(1) TEC. 
It was a welcome move in demarcating a boundary between alternative categories of market restrictions. Since the analytical and legal framework applied in Allianz Hungary", Cartes Bancaires ${ }^{8}$ and Dole Food", the "by object and effect" dichotomy has relied upon a more or less unchanged legal understanding. A restriction "by object" is still commonly understood as a behaviour which, by its nature, is likely to have negative effects on the market. It is thus presumed that illegality of "by object" is not based on a presumption of anti-competitive effects, but rather on an intrinsic nature of that constraint (Chapman and Goyder, 2016, p. 318). An agreement between commercial entities is therefore considered restrictive "by object" if it harms competition, for instance, by having a negative impact on the price, quality or quantity of goods and services. Instead, a restriction "by effect", being read disjunctively, exists when a coordination between undertakings cannot be regarded by its very nature as being harmful to the proper functioning of competition. Hence, if a legal test to identify an object restriction fails but there is still (even potential but appreciable) negative impact on competition, a detailed review of an agreement and its economic context should be conducted in order to allocate it to one of the boxes (Whish and Bailey, 2015, p. 127).

\section{Current state of "by object" matters}

The distinction between "by object and effect" has been confirmed by consistent jurisprudence over many years ${ }^{10}$. It was stressed by competition law practitioners and scholars ${ }^{11}$ that the concept of restriction "by object" should not be given an unduly broad interpretation, nor should it be interpreted so narrowly as to deprive it of its practical effectiveness. Warnings against the mingling of an object and effect analysis have been heard loud and clear, but have never stopped the discussion on where to draw the line between the two categories of distortions. Ultimately, no exhaustive list of such practices exists even now. In fact, a detailed review of relevant jurisprudence makes it possible to even bring up the issue of the creation of a potential "third box", hovering

7 Case C-32/11 Allianz Hungária Biztosító Zrt. v Gazdasági Versenyhivatal.

8 Case C-67/13 P Groupement des cartes bancaires (CB) v Commission.

9 C-286/13 P Dole Food and Dole Fresh Fruit Europe v Commission.

10 E.g. in judgment of the ECJ of 4 June 2009, Case C-8/08 T-Mobile Netherlands BV v Raad van bestuur van de Nederlandse Mededingingsautoriteit, ECLI:EU:C:2009:343, para. 28; judgment of the ECJ of 20 November 2008, Case C-209/07 Beef Industry Development Society and Barry Brothers, ECLI:EU:C:2008:643, para. 15.

11 E.g. point 65 of the opinion of Advocate General Cruz Villalón in Allianz Hungária Biztosító and Others and point 44 of opinion of Advocate General Kokott in T-Mobile Netherlands and Others. 
somewhere between the object and the effects "boxes". Nevertheless, since there is no basis for such division in the TFEU, creating it could only add unnecessary obscurity to this already ambiguous sphere (Whish and Bailey, 2015, p. 127).

The debate on what constitutes a restriction "by object and effect" has been going one for almost fifty years. It should be stressed that an overuse by competition authorities of the "by object" category resulted in much academic commentary (Rose and Bailey, 2013, para. 2.117). The main point in the recent debate is the fact that it is not possible to precisely define the content of the "object box". The question remains current as within the EU the Commission continues to apply the latter concept, most recently in its ongoing proceedings against corporate giants (Newman and Ruubel, 2016). The polemic is particularly relevant in practice, visible by how the "by object" concept is used in the probe concerning the agreements between Hollywood studios and pay-TV broadcasters such as Canal Plus and Sky UK ${ }^{12}$. The Commission has come to the preliminary view that certain contractual obligations in Paramount's agreement with Sky UK Limited and Sky Plc. (which prevented or limited Sky from responding to unsolicited requests from consumers located outside Sky's licensed territory), had as their object the restriction of competition within the meaning of Article 101(1) TFEU. The pay-TV investigation shows the updated approach to the application of antitrust rules to new digital markets. Yet it is targeted specifically to the clarification of the modern understanding of the "by object" concept. Fifty years after the European Court of Justice first ruled on whether agreements can breach antitrust law by their very nature, the European judiciary is still looking at this complex issue.

\section{Recent examples of the application of "by object"}

The validity of the "by object" concept has not diminished and it has recently become a matter of a new precedence. For the first time, the Norwegian Supreme Court has asked the Court of Justice of the European Free Trade Association States (EFTA court) to give its opinion on an allegedly "by object" case (Newman and Eccles, 2016) with respect to a joint bid for a public contract by two taxi cooperatives that was labelled as having a "competition-restrictingobject"13. A Norwegian appeals court held that a joint bid for a public

12 Case AT.40023, Paramount Pictures commitments of 22 April 2016, available at: http:// ec.europa.eu/competition/antitrust/cases/dec_docs/40023/40023_4638_3.pdf.

13 EFTA Court, Case E-3/16, Ski Taxi $S \bar{A}$, Follo Taxi $S A$ og Ski Follo Taxidrift AS v staten v/Konkurransetilsynet. 
transport contract was anti-competitive "by object", irrespective of whether it actually resulted in less intense competition on the relevant market. The case was appealed and has now taken an interesting turn. Despite the apparent mundane nature of the so-called "taxis case", it contributed a valuable element to the debate. What the Norwegian and Latvian cases have in common is the important finding whereby: if there seems to be an insufficient legal basis for applying the "by object" approach, it is not impossible for the practice to be deemed illegal on the basis of an investigation into its likely effects. However, an intrinsic anti-competitive nature cannot be presumed and based solely on datasets such as those presented in the Maxima Latvija or Oslo taxis case seeing as it was not obvious that the non-compete clauses or joint bid, respectively would have had inherent anti-competitive effect. Unfortunately, despite much criticism on the expansive view on "by object" restrictions, the issue keeps reappearing.

\section{Logic and features of the "object box"}

Some agreements may be found to be restrictive "by object" in light of their particular characteristics or their context while others, which appear to contain object restrictions, might be found not to do $\mathrm{so}^{14}$. A clear line between the two types of restrictions would certainly help define them correctly. However, there is still no "test of time", albeit some antitrust lawyers called as such the balancing approach criteria presented in the French Cartes Bancaires case. This ruling was seen as suggesting that the Commission should take a narrow view of what kind of agreements belong to the "object box", not even because of theoretical categorisation motives, but in order to distinguish legality from illegality (Newman and Ruubel, 2016). As aptly diagnosed in the opinion to Cartes Bancaires by Advocate General Wahl ${ }^{15}$, a clear line between "object" and "effect" would bring three benefits to the competition doctrine. First, such delineation would bring legal certainty from being able to anticipate potential legal consequences of certain market actions. Second, identification of agreements, decisions and concerted practices which have the "object" of restricting competition would work as a deterrent and help prevent anti-competitive conduct. Lastly, a clear distinction between "by object" and "by effect" would further procedural economy, in so far as it would provide economic efficiency for competition authorities with respect to time-consuming and often complex examinations of potential or actual market effects.

\footnotetext{
14 Ibidem, p. 132. See also Broadcast Music Inc v CBS 441 US (1979), U.S. Supreme Court.

15 Opinion of Advocate General Wahl delivered on 27 March 2014, Case C-67/13 P Groupement des cartes bancaires v Commission, para. 35 .
} 
Examining the $C B$ case indirectly, the $C J$ confirmed the postulates put forward by Advocate General Wahl. The Court emphasised that certain findings made by the General Court fall within the examination of "effects" on competition, not the "object" of the agreement ${ }^{16}$. Indeed, there is no need to search for the obvious, or move beyond criteria of the object analysis. The recognition of the criteria of an "object" and an "effects" analysis would allow antitrust officials to avoid a burdensome investigation of the effects of suspicious behaviour, provided the context of the case allows them do to so. It is thus to the best interest of the authorities to have a palpable guidance on their analysis, and have a clear line drawn in-between. Additionally, a narrowly defined "object box", and a strict interpretation of the provision of Article 101(1) TFEU, pursues the goal of the rationalisation of the legal concept at hand, an issue encouraged for a number of decades now.

On the other hand, an open-ended nature of the "object category", as well as an alternative relation between object and effect, argues that a restriction of competition "by object" cannot be reduced to only those agreements which "obviously restrict competition". As clearly spelled out in Beef Industry ${ }^{17}$, it is not only the content of an agreement but also its legal and economic context which must be taken into account. A classification as a restriction of competition "by object" cannot depend on whether the object is clear at first sight, or becomes evident upon closer examination while taking account of the intentions of the parties (Ezrachi, 2014, p. 93). The criteria of "by object" and "by effect" analysis do not overlap and cannot be misused in that way. An agreement is either restrictive because of its object, or it is void because it has the potential to result in a prevention, restriction or distortion of competition within the internal market.

The distinction between "object" and "effect" has important practical implications. It is also inextricably interlinked with competition law concerns on the dismantling of the two categories of restrictions. The circumstances of the case at hand inclined the $\mathrm{CJ}$ to reiterate the wider implications of the judgment. Despite the recent proliferation of the tendency to expand the "by object" category, the Maxima Latvija case amounts to the justified conclusion that the two variations are alternatives and as each others' alternatives - they need not be tested cumulatively. Nevertheless, the extent to which the market needs to be elaborated depends on the circumstances and, as a rule, requires a more sophisticated economic analysis with respect to the

16 Judgment of the CJ of 11 September 2014, Case C-67/13 P Groupement des cartes bancaires $(C B)$ v. Commission, para. 81.

17 Beef Industry, paras 15-16. An agreement may, however, be regarded as having a restrictive object even if it does not have the restriction of competition as its sole aim but also pursues other legitimate objectives. 
qualification of effects (Wendt, 2013, p. 256). Limited contractual exclusivity, granted to Maxima Latvija, albeit not seen as anti-competitive as such, had the potential to significantly distort competition. Hence, the CJ went on to extensively explain that if the restriction had fallen into the "by object" category, then the character of a non-compete clause would not have required the support of any economic evidence. Supposing differently would mean that the requirement of certain quality and specific weight of harm contained in an agreement required in order to omit a broader effect analysis would lack a legal justification. Such supposition would mean that competition authorities would have "carte blanche" to decide whether to conduct a full economic analysis or not, regardless of the guidelines of the TFEU. This could clearly undermine legal certainty and allow the authorities to hand down findings without fair limits on the boundaries of the "object category".

\section{Three-tier analysis}

Unfortunately, the Court was not very explicit in Maxima Latvija as to why it ruled the way it did. It went on, however, to explain the main criteria to be applied on the issue of substance.

In order to determine harm to the proper functioning of competition surrounding commercial lease agreements, a comprehensive analysis shall be three-tiered and include the following factors:

1) access to the relevant market - economic, administrative and legal barriers for a new entrant - the CJ went on to say that the veto could potentially distort competition if there were certain limitations placed on the occupation of commercial premises in other shopping centres located in next-door areas;

2) competitive forces on the relevant market - the number of operators present on the market, the size of the competitors, degree of concentration, customer fidelity to existing brands and their habits;

3 ) contribution of the agreement to market foreclosure (to be analysed if the $1^{\text {st }}$ and $2^{\text {nd }}$ factors are fulfilled) - by an investigation of the position of the contracting parties on the market in question and the duration of the agreement (non-compete clauses).

By a way of example, if there are certain barriers which limit accessibility to commercial land and if additional limitations come into play (e.g. administrative limitations on the acquisition of neighbouring land, lack of land for sale in the relevant area, unreasonably high prices for the acquisition of commercial land in comparison to the price paid by the incumbent), the extent of the 
contribution of each agreement to that closing-off effect will in practice determine the final assessment. As a result, if, hypothetically, an agreement with a veto clause would be concluded for a period of 10 years and at least one of its parties had strong market power, such agreement is likely to be considered to have the "effect" of preventing/restricting/ distorting competition within the meaning of Article 101(1) TFEU.

\section{Decisive impact of market foreclosure}

It is difficult to pin down exactly how the presumption of negative effect differs from agreements which are "by nature likely to have negative effects" (Chapman and Goyder, 2016, p. 319). Jurisprudence on market foreclosure was, however, in line with the Cartes Bancaires judgment and earlier rulings on the scope of object restrictions. Relying on analogy to Delimitis ${ }^{18}$, the CJ emphasised that the closing-off effect of non-compete clauses will be cumulative and so several factors (market position, duration of the agreements) need to be taken into consideration.

Where "object" was ambivalent, the CJ looked for actual or potential foreclosure of third parties via barriers to entry. In compliance with core recent standards, the analysis of the "effect" of the investigated conduct referred to the "theory of harm" as an economic narrative in order to explain why it was believed that the conduct in question would adversely affect competition in the retail market. European jurisprudence has tended to adopt a broad interpretation of foreclosure, an approach visible in the Maxima Latvija judgment as well. Foreclosure on the retail market would not only consist of eliminating existing competitors but also their weakening, as well as preventing existing competitors from expanding and deterring potential competitors from entering the market ${ }^{19}$. In truth, foreclosure is not an absolute term and is only one of the negative market effects that may result from an agreement which Article 101(1) TFEU aims to prevent (Rose and Bailey, 2013, p. 142). Nevertheless, in Maxima Latvija, the CJ seemed to be particularly concerned with the prevention of existing competitors from expanding on the market.

18 Judgment of the ECJ of 28 February 1991, Case C-234/89 Stergios Delimitis v Henninger Bräu $A G$, EU:C:1991:91, para. 25.

19 See e.g. Morgan Stanley/Visa International and Visa Europe, T-461/07 Visa v Commission, judgment of the GC of 14 April 2011, ECLI:EU:T:2011:181. 


\section{Code of conduct}

Should developers and tenants always seek advice while introducing a veto clause into their lease agreements? There cannot be any foregone conclusion drawn simply from the existence of such veto rights in lease agreements. Key in making an assessment here would be the economic context and the content of contractual arrangements between the relevant parties. Although the analysis of market effects takes into account potential competition, as protected by competition law, the fact that an agreement could be presumed to have an anti-competitive effect does not automatically mean that a restriction by object exists.

Under these commercial circumstances, the classification of lease agreements seems to be of particular importance. The relationship between landlords and tenants, unlike other vertical agreements, falls into a category of arrangements that because of their subject matter cannot benefit from a block exemption under the conditions set out in the Vertical Block Exemption Regulation ${ }^{20}$. As a result, it is not possible to presume the legality of such agreements and so the criteria of Article 101(1) TFEU are fully applicable. As long as the contractual relationship at hand falls outside the scope of supply agreements, the block exemption provided for vertical agreements for goods or services delivered by a supplied to a buyer does not apply ${ }^{21}$. Being well aware of the risk, such hidden agenda should encourage retail food market players to reconsider the idea before they succumb to incentives to contractually exclude competing supermarkets.

\section{Conclusion}

After many years of a vibrant debate, the issue of what constitutes a competition restriction "by object" continues to be a popular topic of legal discussion. The case at hand suggests that what lies at the heart of the distinction into the two types of restrictions is the categorisation which agreements fall into the "object box" as defined by their effects on the market. In Maxima Latvija, the CJ seems to sustain the assumption that competition authorities

20 Commission Regulation (EU) No. 330/2010 of 20 April 2010 on the application of Article 101(3) of the Treaty on the Functioning of the European Union to categories of vertical agreements and concerted practice, OJ L 102, 23.04.2010, p. 1.

21 European Commission Guidelines on Vertical Restrains, OJ C 130, 19.05.2010, p. 1, para. 26. 
should take a narrow view of what kind of agreements can be considered antitrust violations "by object". There could be no clear-cut "by object" infringement, as has been argued, for instance, in the pay-TV broadcaster example. As emphasised by J. Owen Forrester, "labelling" conduct as a "by object" infringement "can free regulators and judges from making further inquiry into the reality of what is happening" 22 .

It seems that the debate over "by object" and "by effect" will continue. Thus, it will be a tall order not even to formulate a brief clause, but to make sure that the test of Maxima Latvija case law would not appeal. This certainly leaves the door wide open for brave companies which are not afraid to take a risk of potential consequences of such contractual arrangements, or simply have the time and the resources to conduct the three-tier analysis beforehand.

\section{Literature}

Chapman, A. and Goyder, J. (2016). SIA Maxima Latvija: More on "Object" Restrictions in Vertical Relations. Journal of European Competition Law and Practice, 7(5).

Ezrachi, A. (2014). EU Competition Law, An Analytical Guide to the Leading Cases. Oxford and Portland, Oregon: Hart Publishing.

John, L.E. and Turner, J. (2015). Bellamy \& Child, European Union Law of Competition, Second Cumulative Supplement to the Seventh Edition. Oxford: Oxford University Press.

Newman, M. and Eccles, M. (31 March 2016). By-object breaches to get European court guidance, MLex market insight). http://mlexmarketinsight.com/.

Newman, M. and Ruubel, S. (22 March 2016). Cartes Bancaires ruling may offer "more reliable" approach to antitrust conduct, Forrester says, MLex market insight. http:// mlexmarketinsight.com/.

Rose, V. and Bailey, D. (eds). (2013). Bellamy and Child, European Union Law of Competition. Oxford: Oxford University Press.

Wendt, I.E. (2013). EU Competition Law and Liberal Professions: An Uneasy Relationship? Leiden-Boston: Martinus Nijhoff Publishers.

Whish, R. and Bailey, D. (2015). Competition Law. Oxford: Oxford University Press.

22 "Object or Effect? Judicious Thoughts on Classic Themes", Competition Law Association, speech from 21 March 2016 after (Newman and Ruubel, 2016). 